\title{
EFFECT OF LEAD TREATMENT ON THE STIPE AND LEAFLET ANATOMY OF Pteris vittata AND Pityrogramma calomelanos (PTERIDACEAE: FERN)
}

\author{
${ }^{1 *}$ Bamigboye, R. A., ${ }^{2}$ Yusuf, A. A. and ${ }^{2}$ Oloyede, F. A. \\ ${ }^{1}$ Natural History Museum, Obafemi Awolowo University, Ile-Ife, Nigeria. \\ ${ }^{2}$ Department of Botany, Obafemi Awolowo University, Ile-Ife, Nigeria. \\ *Corresponding author's e-mail address: bamigboyeadebola@yahoo.com. \\ (Received: $14^{\text {th }}$ November, 2019; Accepted: $31^{\text {st }}$ March, 2020)
}

\section{ABSTRACT}

\begin{abstract}
The effect of various concentrations of Lead on stipe and leaflet anatomy of Pteris vittata and Pityrogramma calomelanos were investigated. Fernlets were transplanted into $5 \mathrm{~kg}$ pots of soil pre-treated with five different concentrations of Lead, adequately watered and arranged in a complete randomized design in the screen house. Pots with no Lead treatment served as control. At twelve weeks after planting, plants were carefully removed, washed and taken to the laboratory. Anatomical sections of leaflets and stipe of each of the treatments were carried out with a sledge microtome $(10-15 \mu \mathrm{m})$. Microscopic observations of structures were made after staining the sections. In Pteris vittata, the thickness of the cuticle of the stipe increased with increasing Lead concentrations but the reverse of this was observed in Pityrogamma calomelanos. There was also significant reduction of epidermal and mesophyll cell area of both species with increasing Lead concentrations. It can be concluded from this study that P. vittata has a higher tolerance level to Lead than Pityrogramma calomelanos.
\end{abstract}

Key words: Anatomy, Cuticle thickness, Ferns, Lead, Pteridaceae.

\section{INTRODUCTION}

The Pteridaceae is a very interesting group of plant family due to the great heterogeneity of its genera and species, coupled with the fact that it is a family with large representation and importance in floristic level (Smith et al., 2008). Among the families of Pteridophyta, the most representative was Pteridaceae family, with about 35 genera and presents a wide geographical distribution (Gracano et al., 2001). The main characteristics of the family include possession of linear marginal sori with false indusium (Rothfels, 2008). P vittata have been established as an hyperaccumulator $(\mathrm{Ma}$ et al, 2001; Oloyede et al., 2012; Akomolafe et al., 2017). Pteris vittata and Pityrogramma calomelanos are members of the family Pteridaceae. Both were commonly found growing on drainage systems and at bases of water tanks in Southwestern Nigeria. Unlike Pityrogramma calomelanos, P. vittata were never observed growing in shaded forest (Bamigboye, 2018).

\section{Pteris vittata Linn.}

Pteris vittata known as 'Chinese ladder brake fern', is a native of China and also found all over the world, including Nigeria. It is a terrestrial, perennial herb with excellent ornamental value. Its young fronds are used traditionally as an astringent. Benjamin and Manickam (2007) reported that Pteris vittata extract is used as demulcent, tonic, in treating hypotensive, as well as an antiviral and antibacterial agent. Its rhizome is sub-erect with pale brown scales; frond is pinnate, dull brown in colour, widely opened, or spreading with dense scales. The leaflet is long, lanceolate, green, simple, unipinnate, hairy with acuminate apex. Terminal pinna is usually the longest among the pinnae. Stipe is short and polished black. The venation is with free veins, which are dichotomously branched. Sori form two rows, linearly arranged on the margins of the abaxial surfaces of the pinnae. Propagation is by the spores and from the rhizomes. Several studies have reported the presence of leucocyanidin, leucodelphinidin, the flavone ester apigenin 7-Op-hydroxybenzoate and a number of glycosides of apigenin, leutolin, isocutellarein-8-O-methylether, kaempherol and quercetin (Salantina and Prado, 1998; Imperato, 2006). Pteris vittata contains potent antimicrobial properties especially against gastrointestinal tract pathogens and the presence of rutin may in part be responsible for added activity (Meenakshi et al., 2008). Pteris vittata have been identified as an Arsenic (As) hyperaccumulator (Akomolafe et al., 2017) in having an efficient arsenic accumulation capability as well as 
an extensive root system (Komar, 1999; Ma et al., 2001).

In addition, Pteris vittata has the ability to reduce arsenate (arsenic in soils) to $\mathrm{As}^{3+}$ (Ma et al., 2001). It has been proposed that when the plant is exposed to As and under the reducing conditions of plant cells, $\mathrm{As}^{5+}$ is readily reduced to $\mathrm{As}^{3+}$ in hyperaccumulators and then may be complexed by organic ligands such as thiols to avoid damage to plant cells (Zhang et al., 2002).

\section{Pityrogramma calomelanos (Linn.) Link}

Pityrogramma calomelanos Linn. is a native of $\mathrm{New}$ Zealand and is commonly called gold back or silverback fern. It grows in the open areas or slightly open or shaded areas under the forest or re-growth forest. It is regarded as an "opportunist" because it rapidly colonizes bare ground (Campos et al., 2018). It is one of the primary colonizers of volcanically devastated areas. It is a tall, erect, bushy plant with ornamental and medicinal values. The rhizome is short, erect, bearing a tuft of fronds, which are lanceolate, fertile and covered with scales. The scales are brown, narrow, 3-6 $\mathrm{mm}$ long. Stipes are up to 30 $\mathrm{cm}$ long, dark purple, polished, scaly on lower part, glabrous upwards, covered with white powder in young stage. Leaf is bipinnate, pinna is glabrous and densely covered with yellow to orange and whitish powdery substances on the abaxial surface. The leaf is compound bipinnate with 70-100 pinnae arranged in an alternate manner. Pinna is lanceolate, having acute to acuminate apex. The leaf is $17.80 \mathrm{~cm}$ long and $4.28 \mathrm{~cm}$ wide. Plant decoction is used in treating renal disorders in the Philippines. Tea prepared out of the frond is used as a cure for hypertension, fever and cough (Sajeey et al., 2015). Rhizomes are considered anthelmintic in South Africa. Frond decoction is taken for boils in the mouth and nose. Fronds are also used for asthma, cold and chest congestion (Benjamin and Manickam 2007). Pityrogramma calomelanos could be a source of plantderived natural products with anti-epimastigote activity and low toxicity, representing an interesting alternative to other efforts to combat infectious diseases such Chagas disease (De Souza et al., 2012).

Lead is considered a general protoplasmic poison, which is cumulative, slow acting and subtle. The exposure of Lead on human and animals has toxic effects on kidney and the endocrine system (Assi et al., 2016). Plants growing near highways are usually exposed to more Lead than other localities. Sewage sludge containing large quantities of Lead and other metals is regularly discharged on to field and garden soils due to increasing trends in urbanization (Paivoke, 2002). Lead-affected soils contain Lead in the range of $400-800 \mathrm{mg} \mathrm{Kg}^{-1}$ whereas in industrialized areas the level may reach up to $1000 \mathrm{mg} \mathrm{Kg}{ }^{-1}$ of Lead in the soil (Angelone and Bini, 1992).

Plant roots rapidly respond to the absorbed $\mathrm{Pb}$, through a reduction in growth rate and change in branching pattern. In Zea mays seedlings, Obroucheva et al. (1998) observed strong growth inhibition of primary root and a shorter branching zone with more compact lateral roots occupying a position much closer to the root tip compared with roots grown in the absence of Lead. It appears that the inhibition of root growth under Lead toxicity is as a result of Lead induced inhibition of cell division in root tips (Fun et al., 2002). When the effect of different concentrations of Lead nitrate was studied on root growth, cell division, chromosome morphology and the nucleolus of root tip cells of onion (Allium cepa), a reduction in root growth, mitotic irregularities and chromosome stickiness were observed (Wierbicka, 1994). In corn seedlings, Lead toxicity causes leakage of $\mathrm{K}^{+}$from root cells (Malkowski et al., 2002).

This study is aimed at comparing the tolerance of Pteris vittata and Pityrogramma calomelanos and also to determine the effects of the different concentrations of Lead on the anatomical features of the two plants.

\section{MATERIALS AND METHODS}

The study site for this experiment was in the Department of Botany, Obafemi Awolowo University, Ile-Ife (070 $\left.30^{\prime} \mathrm{N}, 04^{\circ} 40^{\prime} \mathrm{E}\right)$, Nigeria. Experimental plants were collected from the fern garden and cultivated in the same Department.

\section{Soil Preparation}

The soil sample used for this study was randomly collected from the top soil, $0-20 \mathrm{~cm}$, behind 
Department of Botany, Obafemi Awolowo University, Ile-Ife. The soil was air-dried for a week, and sieved using $2 \mathrm{~mm}$ mesh gauze to remove debris. The physical properties of the soil were determined using standard method (Gee and Bauder, 1986). X-ray fluorescence was used to determine the background knowledge of the chemical properties of Lead in the soil and in the parent plants. Sixty plastic pots $(24 \mathrm{~cm} \times 21 \mathrm{~cm})$ perforated at the base to allow aeration and drainage were filled with $5 \mathrm{~kg}$ of the soil. Plastic trays were placed under each pot for the collection of excess water to prevent loss of pollutants. For each of the plant species, five pots were labelled as control (CT) and five pots each of the treatments as A, B, C, D and E. These pots were thoroughly saturated with water and arranged in a completely randomized design. The pots labelled as A, B, C, D and $\mathrm{E}$ were treated with different levels of Lead concentrations in the form of Lead (II) trioxonitrate (v) salt $\left[\mathrm{Pb}\left(\mathrm{NO}_{3}\right)_{2}\right]$, that is, $200 \mathrm{ppm}$, $400 \mathrm{ppm}, 600 \mathrm{ppm}, 800 \mathrm{ppm}$ and $1000 \mathrm{ppm}$ respectively in five replicates.

\section{Plantlets Transplanting}

This was carried out after two-day of equilibration of the prepared soil. The fernlets used for this study were obtained from the vegetative propagation of the parent plants. Healthy fernlets of both Pteris vittata and Pityrogramma calomelanos having two leaflets were transplanted into each of the pots and were treated with varying quantities of Lead. This experiment was monitored for twelve weeks after transplanting.

\section{Anatomical Studies}

Transverse sections of the stipes of the fronds in each treatment were made at 10-15 $\mu$ m thickness using a rotary microtome. The sections were stained with $1 \%$ aqueous solution of Safranin $\mathrm{O}$ for 15 minutes, washed in distilled water in Petri dishes to remove excess stain and counterstained in $1 \%$ solution of Alcian blue for three to five minutes. They were washed thoroughly in water and dehydrated through series of ethyl alcohol: 50 $\%, 70 \%, 80 \%, 90 \%$ and $100 \%$ and were later mounted in $25 \%$ glycerine for microscopic examinations.

Statistical Analysis: Data were analysed for least significant differences with one-way ANOVA using SAS version 9.2.

\section{RESULTS AND DISCUSSION}

The results of the effect of the various Lead concentrations on the anatomical features of the stipe of the two plant species are summarized in tables 1 and 2 while those of the leaflet sections are on tables 3 and 4 . The result showed that the thickness of stipe in $P$. vittata increased with increasing Lead concentration but decreased in Pityrogramma calomelanos. In the leaflet anatomy of both plant species there was also significant reduction of cell areas as Lead concentrations treatmentincreased.

Table 1: Effect of Various Treatment of Lead on the Stipe Anatomy of P. vittata

\begin{tabular}{|c|c|c|c|c|c|}
\hline & \multicolumn{5}{|c|}{ Important Stipe Anatomical Characters } \\
\hline Treatment & Cuticle thickness & Epidermis & Sclerenchyma cells & Parenchyma cells & Vascular bundles \\
\hline Control & $12.24 \pm 1.2 \mu \mathrm{m}$ & $\begin{array}{l}\text { Single layered, no } \\
\text { intercellular }\end{array}$ & $\begin{array}{l}\text { 3-6 layers of polygonal } \\
\text { cells }\end{array}$ & $\begin{array}{l}\text { Circular, oval- } \\
\text { polygonal cells }\end{array}$ & $\begin{array}{l}\text { U-shaped with } \\
\text { hippocampus xylem }\end{array}$ \\
\hline A & $13.41 \pm 1.25 \mu \mathrm{m}$ & $\begin{array}{l}\text { Single layered, no } \\
\text { intercellular spaces }\end{array}$ & $\begin{array}{l}\text { 3-6 layers of polygonal } \\
\text { cells }\end{array}$ & $\begin{array}{l}\text { Circular, oval- } \\
\text { polygonal cells }\end{array}$ & $\begin{array}{l}\text { U-shaped with } \\
\text { hippocampus xylem }\end{array}$ \\
\hline B & $15.32 \pm 1.98 \mu \mathrm{m}$ & $\begin{array}{l}\text { Single layered, no } \\
\text { intercellular spaces }\end{array}$ & $\begin{array}{l}\text { 3-6 layers of polygona } \\
\text { cells }\end{array}$ & $\begin{array}{l}\text { 1Circular, oval- } \\
\text { polygonal cells }\end{array}$ & $\begin{array}{l}\text { U-shaped with } \\
\text { hippocampus xylem }\end{array}$ \\
\hline $\mathrm{C}$ & $16.21 \pm 1.29 \mu \mathrm{m}$ & $\begin{array}{l}\text { Single layered, no } \\
\text { intercellular spaces }\end{array}$ & $\begin{array}{l}\text { 3-6 layers of polygonal } \\
\text { cells }\end{array}$ & $\begin{array}{l}\text { Circular, oval- } \\
\text { polygonal cells }\end{array}$ & $\begin{array}{l}\text { U-shaped with } \\
\text { hippocampus xylem }\end{array}$ \\
\hline $\mathrm{D}$ & $17.98 \pm 2,0 \mu \mathrm{m}$ & $\begin{array}{l}\text { Single layered, no } \\
\text { intercellular spaces }\end{array}$ & $\begin{array}{l}\text { 3-6 layers of polygonal } \\
\text { cells }\end{array}$ & $\begin{array}{l}\text { Circular, oval- } \\
\text { polygonal cells }\end{array}$ & $\begin{array}{l}\text { U-shaped with } \\
\text { hippocampus xylem }\end{array}$ \\
\hline $\mathrm{E}$ & $20.63 \pm 2.65 \mu \mathrm{m}$ & $\begin{array}{l}\text { Single layered, no } \\
\text { intercellular spaces }\end{array}$ & $\begin{array}{l}\text { 3-6 layers of polygonal } \\
\text { cells }\end{array}$ & $\begin{array}{l}\text { Circular, oval- } \\
\text { polygonal cells }\end{array}$ & $\begin{array}{l}\text { U-shaped with } \\
\text { hippocampus xylem }\end{array}$ \\
\hline
\end{tabular}

Legend: -Control, A-200 ppm, B-400 ppm, C-600 ppm, D-800 ppm, E-1000 ppm 
Table 2: Effect of Various Treatment of Lead on the Stipe Anatomy of Pityrogramma calomelanos

\begin{tabular}{|c|c|c|c|c|c|}
\hline \multirow[b]{2}{*}{ Treatment } & \multicolumn{5}{|c|}{ Important Stipe Anatomical Characters } \\
\hline & Cuticle thickness & Epidermis & Sclerenchyma cells & Parenchyma cells & Vascular bundles \\
\hline Control & $10.21 \pm 1.76 \mu \mathrm{m}$ & $\begin{array}{l}\text { Single } \\
\text { layered }\end{array}$ & $\begin{array}{l}\text { No sclerenchyma } \\
\text { layer }\end{array}$ & $\begin{array}{l}\text { Circular - oval cell, } \\
\text { no intercellular } \\
\text { space }\end{array}$ & $\begin{array}{l}2 \text { distinct, oval } \\
\text { shaped vascular } \\
\text { bundle }\end{array}$ \\
\hline A & $9.34 \pm 1.71 \mu \mathrm{m}$ & $\begin{array}{l}\text { Single } \\
\text { layered }\end{array}$ & $\begin{array}{l}\text { No sclerenchyma } \\
\text { Layer }\end{array}$ & $\begin{array}{l}\text { Circular to oval } \\
\text { cell, no } \\
\text { intercellular } \\
\text { airspace }\end{array}$ & $\begin{array}{l}2 \text { distinct, oval } \\
\text { shaped vascular } \\
\text { bundles }\end{array}$ \\
\hline B & $8.54 \pm 1.69 \mu \mathrm{m}$ & $\begin{array}{l}\text { Single } \\
\text { layered }\end{array}$ & $\begin{array}{l}\text { No sclerenchyma } \\
\text { layer }\end{array}$ & $\begin{array}{l}\text { Circular - oval } \\
\text { cell, no } \\
\text { intercellular space }\end{array}$ & $\begin{array}{l}2 \text { distinct, oval } \\
\text { shaped vascular } \\
\text { bundle }\end{array}$ \\
\hline $\mathrm{C}$ & $7.01 \pm 1,72 \pm \mathrm{m}$ & $\begin{array}{l}\text { Single } \\
\text { layered }\end{array}$ & $\begin{array}{l}\text { No sclerenchyma } \\
\text { layer }\end{array}$ & $\begin{array}{l}\text { Circular - oval cell, } \\
\text { no intercellular } \\
\text { space }\end{array}$ & $\begin{array}{l}2 \text { distinct, oval } \\
\text { shaped vascular } \\
\text { bundle }\end{array}$ \\
\hline $\mathrm{D}$ & $5.57 \pm 1.68 \mu \mathrm{m}$ & $\begin{array}{l}\text { Single } \\
\text { layered }\end{array}$ & $\begin{array}{l}\text { No sclerenchyma } \\
\text { layer }\end{array}$ & $\begin{array}{l}\text { Circular - oval cell, } \\
\text { no intercellular } \\
\text { space }\end{array}$ & $\begin{array}{l}2 \text { distinct, oval } \\
\text { shaped vascular } \\
\text { bundle }\end{array}$ \\
\hline $\mathrm{E}$ & $4.43 \pm 1.42 \mu \mathrm{m}$ & $\begin{array}{l}\text { Single } \\
\text { layered }\end{array}$ & $\begin{array}{l}\text { No sclerenchyma } \\
\text { layer }\end{array}$ & $\begin{array}{l}\text { Circular - oval cell, } \\
\text { no intercellular } \\
\text { space }\end{array}$ & $\begin{array}{l}2 \text { distinct, oval } \\
\text { shaped vascular } \\
\text { bundle }\end{array}$ \\
\hline
\end{tabular}

Legend: Control, A-200 ppm, B-400 ppm, C-600 ppm, D-800 ppm, E-1000 ppm

Table 3: Effect of Various Treatments of Lead on the Leaflet Anatomy of vittata

\begin{tabular}{lllllll}
\hline Leaflet structure & Control & A & B & C & D & E \\
\hline $\begin{array}{l}\text { Mean value of } \\
\text { the Upper } \\
\text { epidermis }\end{array}$ & $20.23 \pm 2.4 \mu \mathrm{m}$ & $20.60 \pm 2.2 \mu \mathrm{m}$ & $22.20 \pm 2.45 \mu \mathrm{m}$ & $24.12 \pm 3.12 \mu \mathrm{m}$ & $24.2 \pm 2.9 \mu \mathrm{m}$ & $26.00 \pm 3.1 \mu \mathrm{m}$ \\
$\begin{array}{l}\text { Mean value of } \\
\text { the Lower } \\
\text { epidermis }\end{array}$ & $18.53 \pm 2.1 \mu \mathrm{m}$ & $17.93 \pm 1.9 \mu \mathrm{m}$ & $19.96 \pm 2.4 \mu \mathrm{m}$ & $21.91 \pm 2.62 \mu \mathrm{m}$ & $21.89 \pm 2.1 \mu \mathrm{m}$ & $23.49 . \pm 5.3 \mu \mathrm{m}$ \\
$\begin{array}{l}\text { Mean value of } \\
\text { the Palisade }\end{array}$ & $89.34 \pm 4.52 \mu \mathrm{m}$ & $86.20 \pm 3.9 \mu \mathrm{m}$ & $82.40 \pm 3.52 \mu \mathrm{m}$ & $80.36 \pm 4.30 \mu \mathrm{m}$ & $79.61 \pm 2.43 \mu \mathrm{m}$ & $78.94 \pm 2.56 \mu \mathrm{m}$ \\
$\begin{array}{l}\text { Mesophyll } \\
\begin{array}{l}\text { Mean value of } \\
\text { the Spongy } \\
\text { mesophyll }\end{array}\end{array}$ & $72.14 \pm 3.51 \mu \mathrm{m}$ & $64.21 \pm 3.51 \mu \mathrm{m}$ & $61.42 \pm 5.0 \mu \mathrm{m}$ & $57.20 \pm 3.72 \mu \mathrm{m}$ & $55.61 \pm 2.76 \mu \mathrm{m}$ & $52.94 \pm 4.29 \mu \mathrm{m}$ \\
\hline
\end{tabular}

Legend: Control, A-200 ppm, B-400 ppm, C-600 ppm, D-800 ppm, E-1000 ppm 
Bamigboye $\boldsymbol{e t}$ al.: Effect of Lead Treatment on the Stipe and Leaflet Anatomy

Table 4: Effect of Various Treatment of Lead on the Leaflet Anatomy of Pityrogramma calomelanos

\begin{tabular}{|c|c|c|c|c|c|c|}
\hline $\begin{array}{l}\text { Leaftlet } \\
\text { structure }\end{array}$ & Control & $\mathrm{A}$ & B & $\mathrm{C}$ & $\mathrm{D}$ & $\mathrm{E}$ \\
\hline $\begin{array}{l}\text { Mean value } \\
\text { of the Upper } \\
\text { epidermis }\end{array}$ & $20.46 \pm 2.3 \mu \mathrm{m}$ & $18.24 \pm 1.8 \mu \mathrm{m}$ & $17.50 \pm 2.12 \mu \mathrm{m}$ & $15.12 \pm 1.12 \mu \mathrm{m}$ & $12.1 \pm 1.0 \mu \mathrm{m}$ & $11.34 \pm 1.8 \mu \mathrm{m}$ \\
\hline $\begin{array}{l}\text { Mean value } \\
\text { of the Lower } \\
\text { epidermis }\end{array}$ & $18.11 \pm 1.8 \mu \mathrm{m}$ & $15.9 \pm 1.6 \mu \mathrm{m}$ & $6.00 \pm 2.2 \mu \mathrm{m}$ & $12.9 \pm 1.9 \mu \mathrm{m}$ & $10.89 \pm 2.1 \mu \mathrm{m}$ & $9.21 \pm 0.8 \mu \mathrm{m}$ \\
\hline $\begin{array}{l}\text { Mean value } \\
\text { of the Palisade } \\
\text { Mesophyll }\end{array}$ & $84.10 \pm 3.0 \mu \mathrm{m}$ & $81.12 \pm 3.13 \mu \mathrm{m}$ & $76.92 \pm 4.3 \mu \mathrm{m}$ & $75.41 \pm 3.44 \mu \mathrm{m}$ & $71.24 \pm 3.47 \mu \mathrm{m}$ & $62.10^{`} \pm 3.29$ \\
\hline $\begin{array}{l}\text { Mean value } \\
\text { of the Spongy } \\
\text { mesophyll }\end{array}$ & $79.11 \pm 4.1 \mu \mathrm{m}$ & $68.25 \pm 2.20 \mu \mathrm{m}$ & $63.31 \pm 3.24 \mu \mathrm{m}$ & $61.24 \pm 2.55 \mu \mathrm{m}$ & $55.38 \pm 2.1 \mu \mathrm{m}$ & $50.61 \pm 2.44 \mu \mathrm{m}$ \\
\hline
\end{tabular}

\section{Legend: -Control, A -200 ppm, B -400 ppm, C -600 ppm, D -800 ppm, E-1000 ppm}

Structurally, plants from polluted sites present important modifications to their tissues. Some of the structural modifications include reduction in thickness of palisade parenchyma, spongy mesophyll, epidermis and cuticles (Ekpemerechi et al., 2014). From this study, stipe of Pteris vittata showed a significant increase in thickness of the cuticle as the Lead concentrations increased. This is contrary to the finding of Omosun et al. (2008) and Svetlana et al. (2010) who reported that anatomical properties such as cuticle thickness, stomata index decreases as the level of pollution increased. Increase in the thickness of the cuticles observed may be an adaptation to prevent entrance of other pollutants through the leaves since leaves are the first tissue exposed to pollutants among all other plant tissues. However, the progressive decrease in the cuticle thickness of Pityrogramma calomelanos from the control to treatment $\mathrm{E}$ is similar to the findings of Omosun et al. (2008) and Ekpemerechi et al. (2014).
Ekpemerechi et al. (2014) also suggested that the response of plants to changes in environmental conditions whether anthropogenic or otherwise is species specific. The specificity expressed by plant species point to the fact that species could be considered to be susceptible, threatened or otherwise when exposed to pollutants. The reduction in the epidermal and mesophyll layers of both Pteris vittata and Pityrogramma calomelanos across each treatment agrees with Jahan and Iqbal (1992), who reported a significant reduction in cuticle, hypodermis, palisade and spongy parenchyma cells in polluted environment as compared to non-polluted area. Uaboi - Egbenni et al. (2009) reported similar trend on the effect of industrial effluents on the anatomical structures of Abelmoscus esculentum. Similarly, Akomolafe et al. (2017) reported more pronounced negative impact on the internal structure of $P$. ensiformis than in P. vitata. 


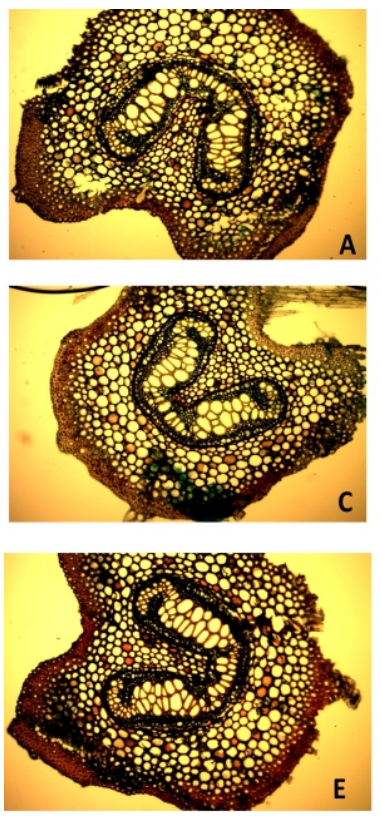

Figure 1a
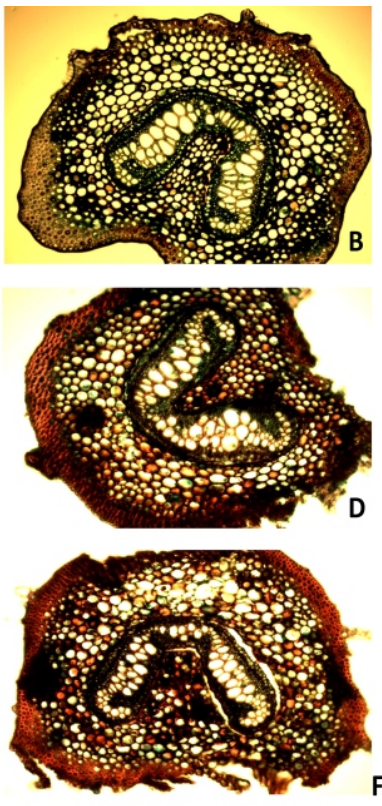
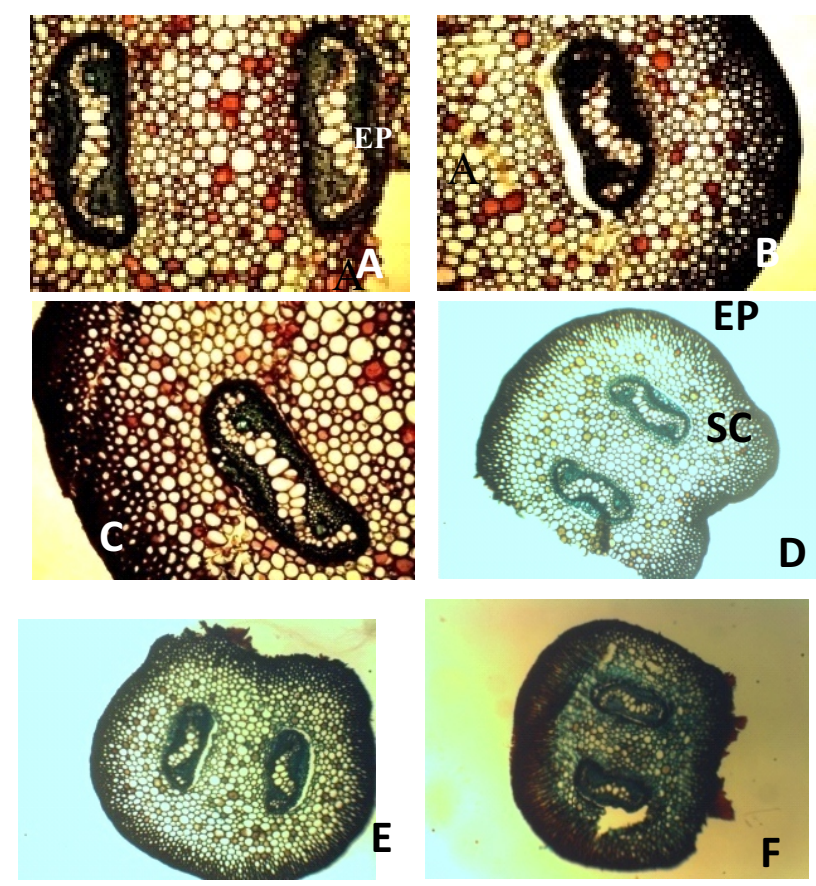

Figure 1b

Mag x400

Figure 1a: The Transverse Sections of the Stipe of Pteris vittata with Varying Lead Treatment Concentrations. Figure 1b: The Transverse Sections of the Stipe of Pityrogramma calomelanos with Varying Lead Treatment Concentrations

Legend: A- Control, B- 200 ppm, C-400 ppm, D-600 ppm, E-800 ppm, F-1000 ppm EP- Epidermis, SC- Sclerenchyma, VB-Vascular Bundle.
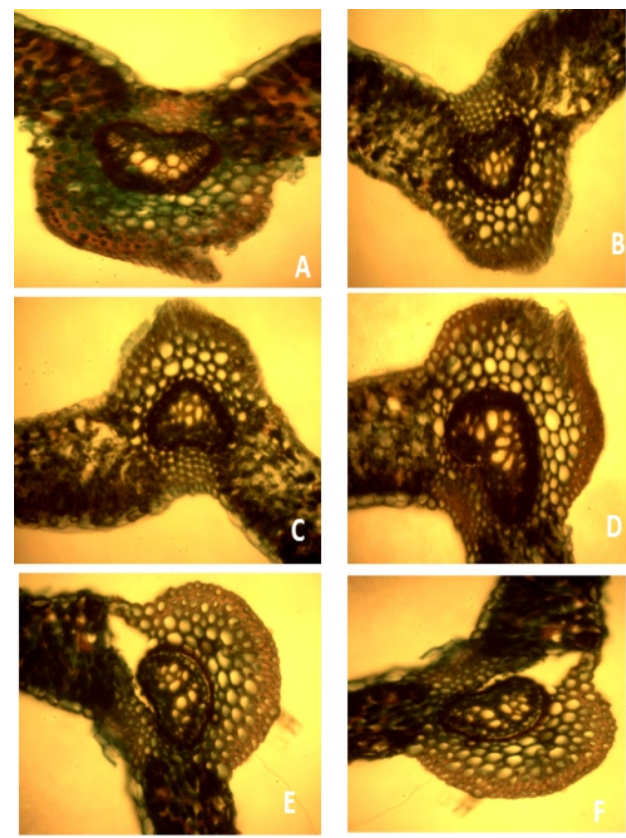

Figure 2a
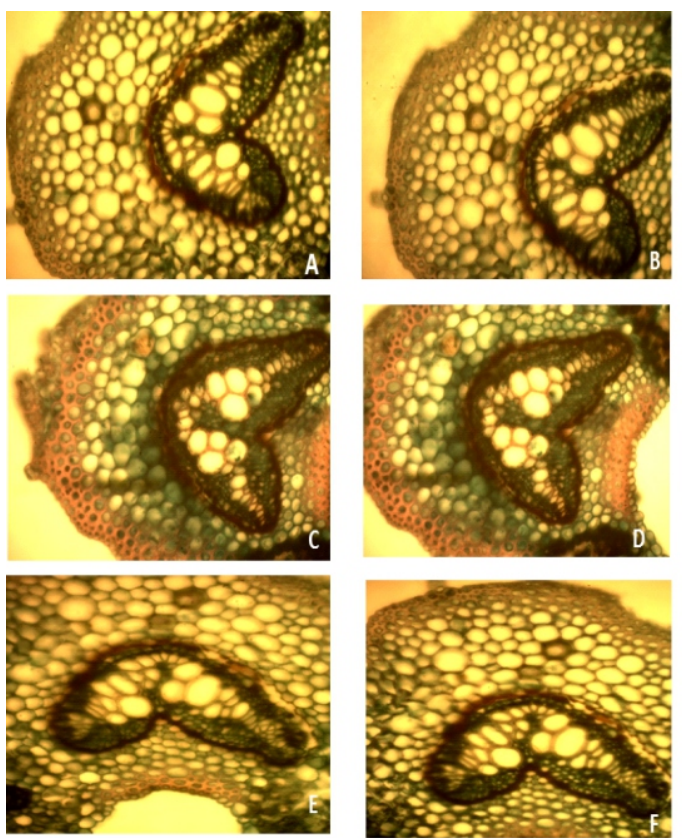

Figure 2b

Mag. $\mathrm{x} 400$

Figure 2a: The Transverse Sections of the Leaflet of Pteris vittata with Varying Lead Treatment Concentrations Figure 2b: The Transverse Sections of the Leaflet of Pityrogramma calomelanos with Varying Lead Treatment Concentrations

Legend: A- Control, B-200 ppm, C-400 ppm, D-600 ppm, E-800 ppm, F-1000 ppm EP- Epidermis, SC- Sclerenchyma, VB-Vascular Bundle. 
Thus, the observed reduction of some anatomical features in the plants used for this study may be attributed to the toxic effect of lead on the plant species. Such anatomical changes are direct consequences of the change in metabolic activities taken place within plants under the influence of heavy metals (Cvetanovska et al., 2010). In the leaflet anatomy, the effect was minimal in Pteris vittata when compared to Pityrogramma calomelanos which showed more reduction in mesophyll cells from control to treatment E. There was no negative effect of Lead on the anatomy of the stipe of Pteris vittata in that the cuticle thickness increased across the treatment. Nevertheless, in Pityrogramma calomelanos the effect was pronounced in the stipe as cuticle thickness decreased progressively with increase in the Lead concentration.

\section{REFERENCES}

Akomolafe, G. F., Oloyede, F. A. and Onwusiri, K. C. 2017. Impact of arsenic stress on leaflets and stipes (Frond Petiole) anatomy of Pteris vittata $L$. and $P$. ensiformis. International Journal of Plant \& Soil Science 17(2):1-9.

Angelone, M. and Bini, C. 1992. Trace elements concentrations in soils and plants of Western Europe, In: Adriano, D.C (ed), Biogeochemistry of Trace Metals Pp19-60 Lewis Publishers, Boca Raton, London.

Assi, M.A., Hezmee, M.M., Haron, A., Mohd Sabri, M., and Rajion, M. 2016. The detrimental effect of Lead on human and animal health. Veterinary World 9(6):660671.

Bamigboye, R.A.2018. Biosystematic study of the Genus Pteris L. (Pteridaceae) in Southwestern Nigeria. PhD Thesis Department of Botany Obafemi Awolowo University, Ile-Ife.

Benjamin, A. and Manickkam, V. S. 2007. Medicinal pteridophytes from western Ghats, Indian Journal of Traditional Knowledge 64(4): 611-618.

Campos, N.V, Arcanjo- Silva, S., Freitas- Silva, L., Araujo ,T.O., Souza-Fernandes, D.P. and Azevedo, A.A. 2018. Arsenic hyper accumulation in Pityrogramma calomelanos L.(Link):adaptive traits to deal with high metalloid concentrations. Environmental
Science and Pollution Research, 25:1072010729

Cvetanovska, L. Klincharska, I. J., Dimeska, G. Srbinoska, M. and Cvetanovska, A. 2010. Anatomic and physiological disorder after intoxication with heavy metals in Tobacco (Nicotiana tabacum). Biotechnology, 24: 57-58.

De Souza, T., Braga, M., Maria., Rogerio, A., Pablo, A. Diones, C. and Bueno, N.S. 2012. Cytotoxic and trypanocide activities of Pityrogramma calomelanos. American Fern Journal 64(1):43-48.

Ekpemerechi, S. E., Lala, M. A., Jimoda, L.A., Odiwe, A.I. and Saheed, S. A. 2014. Effect of air pollution on the foliar morphology of some species in the Family Euphorbiaceae in Southwestern Nigeria. Journal of Science and Technology, 34(1): 2129.

Fun, S. O., Youn, H.S. and Lee, Y. 2002. Lead disturbs microtubules organization in the root meristem of Zea mays. Physiology of Plant, 130: 357-365.

Gracano, D., Alves, A. and Prado, J. 2001. Leaf anatomy of Pteridaceae species from Rio Doce State Park (- PERD) MG. Revista Brasileira de Botanica, 24:333-347.

Gee, G.W. and Bauder, J. W. 1986. Particle size analysis in methods of soil analysis part1 Klute A. (Ed). Soil science society of America Madison Wisconsin, pp.1-67. Include the Publisher

Imperato, F. 2006. The flavone ester Apigenin7-O-oxy-phydroxybenzoate and 3-Di-C glycosylflavones from Pteris vitata American Fern Journal, 96 (2):62-65.

Jahan, S. and Iqbal, M.Z. 1992. Morphological and anatomical studies on leave of different plants affected by motor vehicle exhaust. Journal of Islamic Academy of Sciences 5:2123.

Komar, K. M. 1999. Phytoremediation of arsenic contaminated soils: plant identification and uptake enhancement. Plant Physiology, 122: 1343-1353.

Ma, L. Q., Komar, K. M., Tu, Z.W. and Cal, Y. 2001. A fern that hyper-accumulate arsenic. Nature, 409: 570-579.

Malkowski, E. Kita, A, W., Kare and Michael, K. 2002. Lead distribution in corn seedlings (Zea mays L;) and its effect on growth and 
the concentration of potassium and calcium. Plant Growth Regulator, 37: 69-76.

Meenakshi, S., Govindarajau, R.R. Ajay, K.S. and Prem, B. K. 2008. Antimicrobial Flavonoid rutin from Pteris vittata against pathogenic gastrointestinal microflora. American Fern Journal, 98 (2):98-103.

Oloyede, F.A., Akomolafe, G. F. and Odiwe, A.I. 2012. Arsenic hyperaccumulation and phytoremediation of Pteris vittata and Pteris ensiformis ferns in Nigeria. Acta Hungarica, 955(3-5):377-384.

Omosun, G., Markson, A. A. and Mbanasor, O. 2008. Growth and anatomy of Amaranthus bybridus as affected by crude oil concentrations. American Eurasian Journal of Scientific Research, 3(1):7-74.

Obroucheva, N.V., Bystro, E. I., Ivanov, V. B., Anupova. O. V. and Seregin, I.V. 1998. Root growth responses to lead in young maize seedlings. Plant Soil200:55-61.

Paivoke, A. E. A. 2002. Soil lead alters phytase activity and mineral nutrients balance of Pisum sativum. Environmental Botany, 48: 6173.

Rothfels, C. 2008. Pteridaceae EDM Kirchin, 1831. Brake ferns, maiden ferns and allies http://tolweb.org/Pteridaceae/29352/2 008 12/23 Accessed, 0ctober. 2015.

Sajeey, S., Adarsh, P. and Hegde. S. 2015. Phytoconstituents of Nephrolepis hirsutula and Pityrogramma calomelanos, two medicinal ferns of Western Ghats. Indian Fern Journal, 32:244-256.

Salantina, M.L.F. and Prado, J. 1998. Flavonoid glycosides of Pteridaceae from Brazil. Biochemical Systematics and Ecology, 26:761769.

Smith, A. R., Pryer, K., Schuettpelz, E., Koral, P., Schneider, H. and Paul, W. 2008. Fern Classification. In: Biology and Evolution of ferns and Lycophytes Eds T.A. Ranker and C. H. Haufler, Cambrigde University Press.

Svetlana, S. Veska, S.M. and Dunica, C. 2010. Environmental impact on morphological and anatomical structure of Tansy. African Journal of Biotechnology, 9(16): 2413-2421.

Uaboi-Egbemi, P. O., Okolie, P. N., Adejuyitan, O. E., Sobande, A. O. and Akinyemi, O. 2009. Effects of industrial effluents on the growth and anatomical structures of Abelmoscus esculentum (Okro). African Journal of Biotechnology, 8(14):3251-3260.

Wierbicka, M. 1994. Resumption of mitotic division in Allium cepa root tips during treatment with lead salts. Environmental and Experimental Botany 34:173-180.

Zhang, W., Cai, Y., Tu, C. and Ma, L. Q. 2002. Arsenic speciation and distribution in an arsenic hyper-accumulating plants. Science of TotalEnvironment, 300:167-177. 